\title{
Psychiatry in the Time of Cholera: A Quarter-Century of Albanian Thematic Writings (1959-1984)
}

\begin{abstract}
In the second half of the last century, Albanian society adopted a totalitarian way of communist thinking, that could not have spared medical disciplines. Psychiatry was and probably remains a stigmatized field, whose problems almost never were discussed openly. Specialized writings on psychiatry were available and could shed light on the themes and questions of concern. A periodical journal entitled Psychoneurological Works circulated in its print edition, with its first issue of 1959, its tenth issue of 1984 till it ceased publishing some years later. The journal was a mixture of neurological and psychiatric contributions, with the latter reflecting consistent time-related shifts in thematic, terminology, and data exposure. The panegyric and enthusiastic statements served as a good disguise for the immense ailing of patients and the ethical challenges that psychiatrists were facing, while exerting their profession in the time of severe dictatorship, when the disrespect of human being reached its apogee.
\end{abstract}

Keywords: Albania, communism, neuroleptics, psychiatry, shock therapies

\section{INTRODUCTION}

The public opinion toward psychiatry in Albania has been constantly characterized from mixed feelings: fear, stigma, prejudice, and distance. Attempts to modernize the discipline were systematically made from professionals during the second half of the last century. Strangely (but maybe not that much), Russian scholars had a founder effect on the Albanian psychiatry or pretended to do so. ${ }^{[1]}$ It was the time of the "iron curtain" separating Europe into two camps, and the country needed a system: communism offered one, and its ideological influence could not leave untouched medicine in general, and psychiatry as a discipline. ${ }^{[2]}$

The country has been a blind spot for foreign scholars during all years after relations were cut with Eastern European regimes (1960s) and very few reports are available. Positive voices were isolated when speaking loudly: in 1986, an author appraises the unbelievable achievements of Albanian psychiatry during communism, and while doing that at the Bulletin of the

\footnotetext{
Submission: 29-04-20

Decision: 31-05-20

Acceptance: 04-06-20

Web Publication: 24-12-20

This is an open access journal, and articles are distributed under the terms of the Creative Commons Attribution-NonCommercial-ShareAlike 4.0 License, which allows others to remix, tweak, and build upon the work non-commercially, as long as appropriate credit is given and the new creations are licensed under the identical terms.
}

For reprints contact:WKHLRPMedknow_reprints@wolterskluwer.com
Royal College of Psychiatrists, misspells twice the name of the head of Department of Psychiatry in Tirana. ${ }^{[3]}$ At that time neurology and psychiatry were even treated almost as a single discipline under the common name of neuropsychiatry, but the professor "Bajaraja Praha" heading the department that the author visited, was instead named Bajram Preza, and was a career neurologist and forefather of the Albanian modern neurology.

\section{The Journal}

Psychoneurological Works represented a journalistic venue that was drafted along austere ideological guidelines. The journal was published from the Cathedra of Neuropsychiatry, Faculty of Medicine at the University of Tirana, with the first issue dating 1959 [Figure 1]. There was a long delay (13 years) till the publication of the second issue (1972). Until the year 1984, there have been a total of ten issues; few years thereafter the journal eventually stopped publishing at its $12^{\text {th }}$ issue and the contents fall into almost a complete oblivion.

The Faculty of Medicine in Tirana was part of the state University and published other periodicals as well, with a very short indexing period in the PubMed

How to cite this article: Vyshka G, Mana T, Mihali A. Psychiatry in the Time of Cholera: A Quarter-Century of Albanian Thematic Writings (1959-1984). World Soc Psychiatry 2020;2:225-9.

\section{Gentian Vyshka, Tedi Mana ${ }^{1}$, Alessia Mihali}

Department of Biomedical and Experimental, Faculty of Medicine, University of Medicine, ' Service of Psychiatry, University Hospital Center, Tirana, Albania
Address for correspondence: Prof. Gentian Vyshka, Faculty of Medicine, University of Medicine, Tirana, Albania. E-mail: gvyshka@gmail.com

Access this article online Website: www.worldsocpsychiatry.org

DOI: 10.4103/WSP.WSP_19_20 Quick Response Code: 


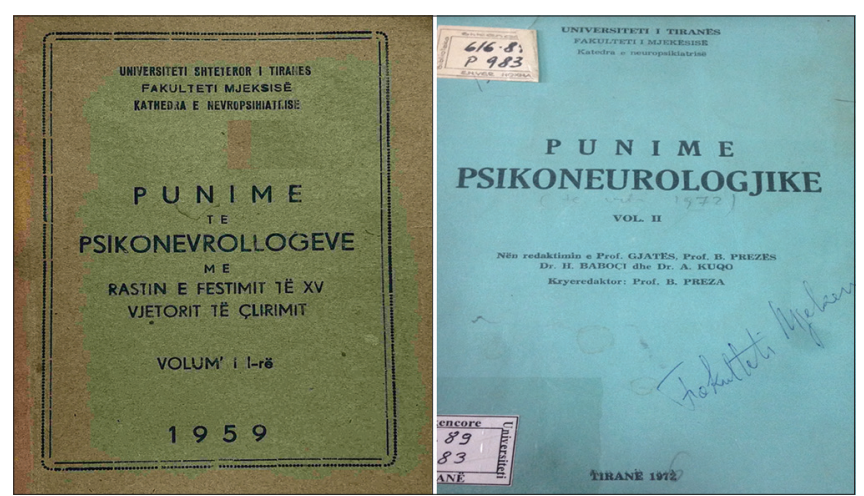

Figure 1: Cover of the $1^{\text {st }}$ issue (1959, left inset: "Works of Psychoneurologists published during festivities on the XV year of liberation") and $2^{\text {nd }}$ issue (1972, right inset: Psychoneurological Works)

during the years 1961-1964 (two journals, Shëndetësia popullore - People's health [NLM ID: 20730110R] and Buletin i Universitetit Shtetëror të Tiranës. Seria Shkencat mjekësore - Bulletin of State University of Tirana. Medical Sciences Serial [NLM ID: 7505300]) and a total of 57 papers indexed, all of those without any abstract available. On the other hand, strictly dedicated journals to a discipline were an exception; nonetheless, the Cathedra of Neuropsychiatry succeeded into publishing its own periodical, among other brochures, textbooks, and treatises.

The journal was in some issues entitled Works of Psychoneurologists, whereas the majority of issues were entitled Psychoneurological Works. Under this specific denomination, the journal's name might be extremely confusing to the actual reader of English background. In fact, psychoneurology is largely a Russian-borrowed term that reflects all the way how psychiatry and especially the Pavlovian theory were embedded in the healing and approaching the mental health issues. ${ }^{[4,5]}$ For the Western reader, instead, psychoneurology is a drug-free alternative to traditional psychiatric and psychological approaches. ${ }^{[6]}$ This is not the case for Albanian patients and their colleagues treated in Eastern European facilities: neuroleptics were used, overused, and abused sometimes to the point of nonreturn.

\section{TERMinOLOGY}

The soviet influences were immense in the first issue, dating 1959 [left inset of Figure 1]. The naming of Cathedra as of Nevropsihiatrisë was irreversibly changed into Neuropsikiatrisë at the second issue, that was published in 1972. This long delay separating just these two initial issues might be connected to the fact that Albania severed relations with the Soviet Union in the early sixties, and all Russian reminiscences were removed or abolished. The term psihiatri - with the "h" typical of the Cyrillic spelling - was Latinicized into "psikiatri" putting the word closer to Italian; the same happened with nevro with a "v" becoming definitely neuro (as neurology in English). The distancing from Russian influence was taken seriously:
Albania chose its own way, that of complete isolation. Changes between the first and the second cover issues were not only terminological. The highly enthusiastic words "published during festivities on the XV year of liberation" written right under the title "Works of Psychoneurologists" of the first issue were replaced with the names of editors in the second issue.

It was not, of course, a very simple thing. Hence, the turning back of eastern influences once and again: the tenth issue, published in 1984, has an article dedicated to the notion of "psychopathoid" something hardly noticeable among the English and American psychiatrists. ${ }^{[7]}$ It was, once again, the reflection of imprints that Albanian authors were striving, willing, or unwilling to forget once and forever. ${ }^{[8]}$ Time effects are obvious all over the ten issues published during 1959-1984; someone will find obsolete or redundant notions that were removed or reformulated during the continuous classifications of psychiatric diagnoses. Among these some authors mention cases of functional aphonia, collective hysteria, ideopressive neurosis, and other rarities that reflect the ever-changing classificatory and diagnostic challenges of psychiatry. ${ }^{[9-11]}$

\section{Thematic Selection: Quare Fremuerunt Gentes (Why Do the PeOple Rage? [FROM the Second Psalm of the Book of Psalms, Holy BIBLE])}

Psychoneurological Works had 129 papers published during the ten issues (1959-1984) from psychiatrists working inside Albanian psychiatric facilities or medical authors writing on a psychiatric theme. The production was never balanced between neurological and psychiatric articles since figures differed from one issue to the other; for example, the second issue (1972) had only 3 psychiatric papers, whereas the ninth issue (1983) had the abundancy of 24 contributions from Albanian psychiatrists.

At the time of publication, the country was strongly isolated and indexing was out of discussion. Furthermore, papers were entirely in Albanian and an abstract in English was not included. A regression was even visible, with the first issue (1959) including at the end abstracts in French for all articles; this was unfortunately not any longer the case. However, papers were sketched according to sound scientific bases, with the majority of them including updated references from French, English, and Russian sources, and a perceived attempt to include statistical and epidemiological notions was clear. Hard copies of the issues could be found actually at the National Library in Tirana as well as at the Library of Faculty of Medicine; and probably in some district libraries as well. All titles (but not contents) have been actually indexed and can be found online at the catalog of the bksh.al (Biblioteka Kombëtare e Shqipërisë - National Library of Albania); while selecting the icon of English as language, one must search inside the 
"Title" with the keyword psikoneurolog (Albanian term for psychoneurologist). ${ }^{[12]}$ A snapshot of the titles actually indexed is shown in Figure 2.

Papers were not separated according to typology; a major classification was made according to source: papers from the Service of Neurology or from Psychiatry. In some cases, district hospitals were honored and contributions from Elbasan, Vlora, and other cities were duly denoted. We made a postfactum classification of the articles on a psychiatric theme or from contributors working in Albanian psychiatric facilities (issues 1-10), and data are summarized in Table 1.

There has been a persistent attempt to shed light on psychopathology: hence the large number of review/ mini-review or perspective articles, describing symptomatology and diagnostic approach to diseases. Rarities were emphatically presented through case reports/ series and when more systematized, as clinical pictures. Under the section of history some five papers were made: most interestingly, a Russian author became the storyteller of the past. ${ }^{[13]}$ Aleksandrovski, a renowned psychiatric authority and a major contributor in the field of psychoactive drug research in the Soviet scientific tradition, was not limited only on that: he became a historian as well. ${ }^{[1,13,14]}$

Narrative methodology was related also to the specificities of the period: articles generally had no sections, no subheadings, no breaks: the reader had to be zealous enough as to pick up any valuable message hidden through the lines. In Figure 3, there is a scanned reproduction of two pages of a manuscript: someone might think about reading a novel or a literary work.

Elements of paternalism are noticeable in some of the papers: patients have no right to confidentiality, and their names, family names, and addresses are disclosed openly inside some of the manuscripts. It was the time when local authors decided to write their own history of psychiatry, a duty previously granted to foreigners. ${ }^{[13,15]}$ Full disclosure of patients' names is not an exclusivity of our sources. ${ }^{[16]}$ However, scholars had abandoned such a position several years before, through anonymizing case reports.

\section{The Miracle Drug and Coming of Age}

Substantial work has been dedicated to new drugs already in the Albanian market and hospitals. Papers describing pharmacological principles have an unprecedented feeling of enthusiasm and release: the magic bullet was found. Articles were mainly related not only to the mechanism of action of the neuroleptics but also to antidepressants and to shock therapies. Contributions were prolific, abundant, and meticulous vis-à-vis the hope to wipe out insanity, as long as authors were talking about complete healing even of severe psychoses. Neuleptil (periciazine) was promoted at the second issue in 1973, and thereafter several other antipsychotics, as to end up even with local experiences such as those reported from psychiatrists of Vlora hospital with Majeptil (thioproperazine), in 1984. ${ }^{[17,18]}$ Reading through continuous and unending lines was not that easy: accidents might happen, but side effects were of less importance when the ends justified the means and the regime was striving to control the only part of society

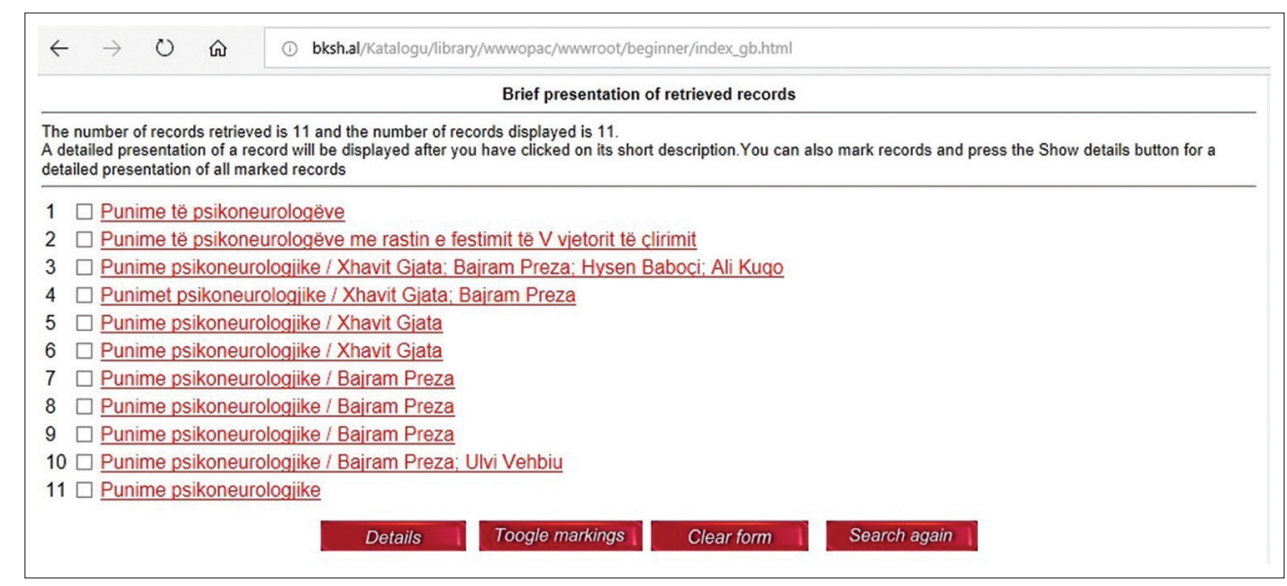

Figure 2: Issues actually indexed in the online catalog of $B K S H$ (National Library of Albania). Contents and titles of separated manuscripts are not indexed; the $5^{\text {th }}$ issue is also missing in this list and the order of appearance does not respect the chronology of the publishing year for the first three items. Numbers 3-10 have a slash mark indicating thereafter the names of editor(s). The option of clicking each item separately is valid and offers further details on the number of pages of each issue, date of publishing, and other data

\begin{tabular}{|c|c|c|c|c|c|c|c|}
\hline \multicolumn{8}{|c|}{ Paper typology: “Psychoneurological Works issues 1-10” (1959-1984) } \\
\hline Review/Perspective & Therapeutics & Public health & Case series & Clinical picture & History & Original research & Case report \\
\hline 53 & 36 & 11 & 8 & 7 & 5 & 5 & 4 \\
\hline
\end{tabular}




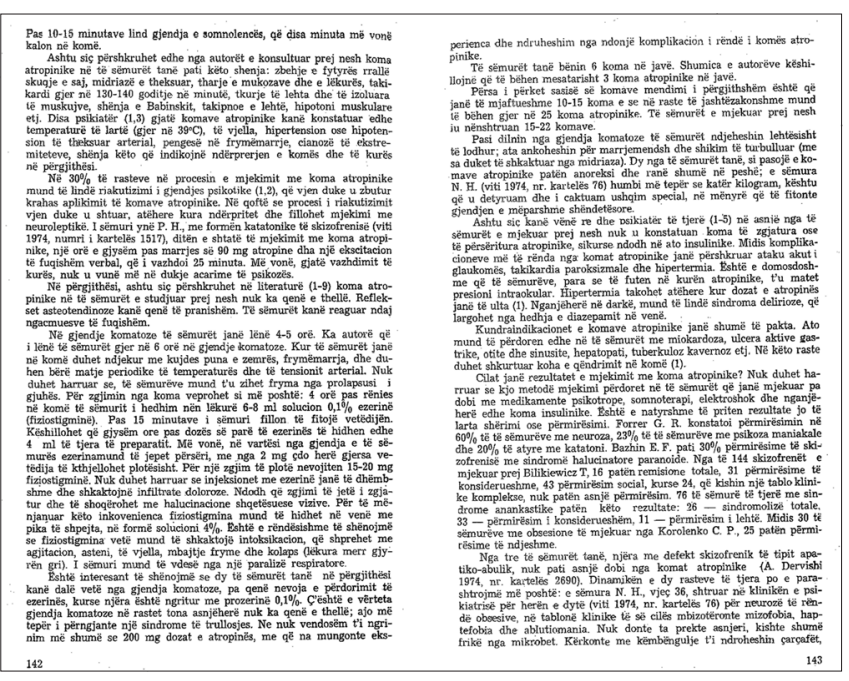

Figure 3: Scanned copy of two pages from a manuscript: the written material was raw and continuous, with no attempts to showcase the details of importance

that was allowed to dissent from the official rules, merely because of being insane. The armamentarium was florid and flourishing with shock therapies applied for years, even decades after being abolished as senseless in other countries. ${ }^{[19]}$

Shock therapies became of concern once someone, while mentioning the excellent results, the imagined healing, and the meaningfulness of the procedure, was so astute as to add somewhere inside the lines that some patients may die. Three articles at the seventh issue were entirely dedicated to strange complications and supportive measures during and following coma therapy with insulin: even nurses were assigned special duties of importance. ${ }^{[20]}$ When Albanian authors report details of care during this therapy in 1977, one should not forget, meanwhile, that insulin coma was already discredited and abandoned in the late 1950s. ${ }^{[21]}$ The reporting of side effects, some of which severe and potentially lethal, was a sign that the discipline was coming of age. Nevertheless, drugs were widely used with few monitoring, especially of the hemodynamic effects: a notorious mixture was the so-called chlorpromazinescopolamine that was applied in spite of serious adversities, even though the neuroleptic chlorpromazine was meant to replace definitely the anticholinergic scopolamine. ${ }^{[22]}$

\section{Conclusions}

Political abuse of psychiatry and unwilling psychiatric treatment of dissidents in a handful of communist regimes gave sufficient material as to foment even antipsychiatry movement. ${ }^{[23]}$ Of course, working under certain circumstances was not an easy duty even for the best prepared and most devoted of medical specialists of psychiatry. ${ }^{[24]}$ In some instances, psychiatrists were emphasizing how good might be atheism for psychiatric patients, as long as religious delusions disappeared among
Albanian patients after the country abolished officially in 1967 all beliefs and spiritual activities. ${ }^{[25]}$

There was an abuse of psychiatric diagnoses and related institutions from the regime, as it might quite well have happened the contrary: a psychiatric abuse with the politics. Working in an off-limits area, with the regime happy to have put aside and expelled from the everyday life hundreds of "crazy" people, psychiatrists have not rarely endorsed political slogans to justify or disguise their misdeeds. The fact is that the pharmacological revolution, which started triumphantly in the Soviet Union, helped little (if at all) to decrease the number of inpatient cases. ${ }^{[26]}$ Albania, in 1975, had little less than two-and-half million inhabitants but appraised the fact that the psychiatric hospital of Elbasan achieved a capacity of 850 beds, three hundred of which were dedicated to chronic, otherwise said, long-life treatment of patients. ${ }^{[27]}$ The exclusion was total: hence, the semantic used in the narratives of the situation was probably, the same.

\section{Financial support and sponsorship}

Nil.

\section{Conflicts of interest}

There are no conflicts of interest.

\section{REFERENCES}

1. Aleksandrovskii AB. Development of psychiatry in Albania. Zh Nevropatol Psikhiatr Im S S Korsakova 1960;60:109-14.

2. Eghigian G. Was there a communist psychiatry? Politics and East German psychiatric care, 1945-1989. Harv Rev Psychiatry 2002;10:364-8.

3. Prasad A. Psychiatry in Albania. Bull R Coll Psychiatr 1986;10:239-40.

4. Timofeev NN. 50 years of psychoneurology in Leningrad. Vopr Psikhiatr Nevropatol 1968;13:5-9.

5. Lavretsky H. The Russian concept of schizophrenia: A review of the literature. Schizophr Bull 1998;24:537-57.

6. Available from: http://pnboard.org/what-is-psychoneurology/. [Last accessed on $2020 \mathrm{Feb}$ 19].

7. Vehbiu U, Lacaj N. Some data over the psychopathoid deficit in schizophrenia. Psychoneurol Works 1984;10:315-8.

8. Kondratév FV. Clarifying the concept of "psychopathoid" in reference to patients with schizophrenia. Zh Nevropatol Psikhiatr Im S S Korsakova 1973;73:915-8.

9. Dibra H. Functional aphonia as a subspecies of hysterical neurosis. Psychoneurol Works 1959;1:19-54.

10. Vehbiu U. Collective hysteria. Psychoneurol Works 1974;4:113-7.

11. Lacaj N. Ideopressive neurosis. Psychoneurol Works 1977;6:122-7.

12. Available from: http://bksh.al/Katalogu/library/wwwopac/ wwwroot/beginner/index_gb.html. [Last accessed on 2020 Feb 19].

13. Aleksandrovski AB. From the history of psychiatry in Albania. Psychoneurol Works 1959;1:5-12.

14. Spivak LI. Psychoactive drug research in the Soviet scientific tradition. J Psychoactive Drugs 1991;23:271-81. 
15. Gjata X. A short history of establishing the service of psychiatry in Tirana. Psychoneurol Works 1974;4:5-12.

16. Jones R. Case of aphonia cured by purgatives. Edinb Med Surg J 1809;5:281-3.

17. Mihali M. The effects of Neuleptyl in a group of psychic patients. Psychoneurol Works 1973;3:187-92.

18. Mitro L, Mihali A. A study on the treatment with Majeptil during a three-year period 1976-1978 in the neuropsychiatric hospital of Vlora. Psychoneurol Works 1984;10:259-61.

19. Vyshka G, Kazaferi A, Kapo I, Mana T. Forbidden insanity: The systematic denial of mental health issues from a state-run psychiatry. Psychiatr Danub 2018;30:385-9.

20. Cenolli I. Nurses' duties toward the prevention and the treatment of complications related during the application of insulin coma. Psychoneurol Works 1977;7:278-81.

21. Jones K. Insulin coma therapy in schizophrenia. J R Soc Med
2000;93:147-9.

22. Ban TA. Fifty years chlorpromazine: A historical perspective. Neuropsychiatr Dis Treat 2007;3:495-500.

23. Moncrieff J. Psychiatric diagnosis as a political device. Social Theory Health 2010;8:370-82.

24. Adler N, Mueller GO, Ayat M. Psychiatry under tyranny: A report on the political abuse of Romanian psychiatry during the Ceausescu years. Curr Psychol 1993;12:3-17.

25. Vehbiu U, Radovani L, Pikuli T. Changes in the psychosis and neurosis presentation during the last 25 years. Psychoneurol Works 1974;4:80-7.

26. Zajicek B. The psychopharmacological revolution in the USSR: Schizophrenia treatment and the thaw in soviet psychiatry, 1954-64. Med Hist 2019;63:249-69.

27. Shqerra H. The activity of the neuropsychiatric hospital during 1963-1973. Psychoneurol Works 1975;5:83-91. 